GOOD GOVERNANCE IN PUBLIC PROCUREMENT: A SOUTH

AFRICAN CASE STUDY

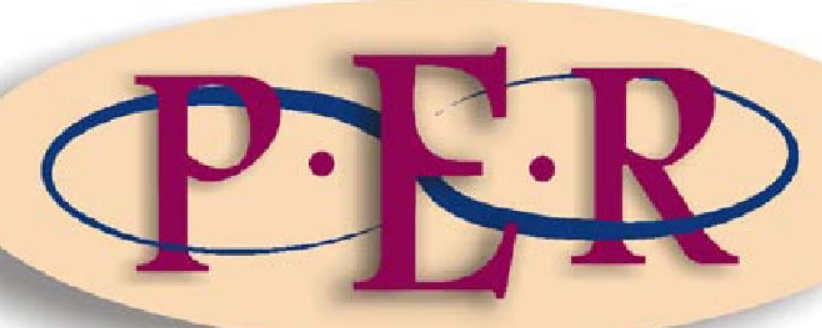

2008 VOLUME 2 


\title{
GOOD GOVERNANCE IN PUBLIC PROCUREMENT: A SOUTH AFRICAN CASE STUDY
}

\author{
R Roos and S de la Harpe*
}

\section{Introduction}

It is a generally accepted principle of good governance that effective legal remedies should be available in the case of the breach of a legal duty by a procuring entity. In public procurement this will, amongst others, ensure accountability, equitability and the integrity of the procurement regime. A number of international instruments contain prescriptions on remedies that will vindicate the rights of participants in the procurement process. It is generally accepted that a range of remedies may qualify as effective and that effective remedies are not limited to orders ad pecuniam solvendam.

In South African law, public tender processes are regarded as administrative processes, but once the tender is awarded, the parties conclude a contract where after their relationship is governed by the law of contract. Public procurement is thus a field where the principles of both public and private law are relevant. Public and private law remedies may also be available to aggrieved parties, depending on the stage in the procurement process and the status of the party. Should a public tender, after it has been awarded and a contract entered into between the parties, be set aside on review, the contract so concluded between the public entity and successful tenderer, is void. This entails that no contractual remedies are available to the initially successful

* Rolien Roos Senior Lecturer and Stephen de la Harpe Associate Professor, Faculty of Law North-West University, Potchefstroom Campus. 
tenderer. In Steenkamp v Provincial Tender Board, Eastern Cape ${ }^{1}$ the Constitutional Court had to consider whether an initially successful tenderer could lodge a delictual claim for damages to compensate for expenses incurred after conclusion of a contract, which was subsequently rendered void on an application for review of the tender award.

The Public Finance Management Act, ${ }^{2}$ which regulates public procurement on national and provincial level, does not address the issue of delictual liability and the question is whether delictual liability would not be an (or the only) appropriate remedy in certain circumstances. This contribution will focus on the reasoning of the various South African courts in the Steenkamp-case in order to establish whether the current legal position on delictual liability in the event of setting aside a tender award, is in conformity with the principles of good governance and the principles as set out in the UNCITRAL Model Law on Public Procurement (hereinafter referred to as the 'Model Law') and the General Procurement Agreement of the World Trade Organisation (hereinafter referred to as the GPA). ${ }^{3}$

The principles of good governance and the provisions on public procurement as contained in the Model Law and the GPA, relating to accountability, with specific reference to the payment of compensation for damages suffered, will be considered first. An analysis of the Steenkamp-decisions will follow. In conclusion, the effect of these decisions will be measured against the

1 Steenkamp v Provincial Tender Board, Eastern Cape 2007(3) SA 121 (CC). The reference of the case as reported in the Supreme Court of Appeal is 2006 (3) SA 151 (SCA). Hereafter the Steenkamp-case.

2 Public Finance Management Act 1 of 1999. The Local Government: Municipal Finance Management Act 56 of 2003, which regulates procurement on local government level, in s 176 provides that: "No municipality or any of its political structures, political office-bearers or officials, no municipal entity or its board of directors or any of its directors or officials, and no other organ of state or person exercising a power or performing a function in terms of this Act, is liable in respect of any loss or damage resulting from the exercise of that power or the performance of that function in good faith."

3 The reason for comparing the provisions of the UNCITRAL Model Law and the GPA is that these two instruments are internationally accepted as benchmarks for public procurement. 
applicable principles of good governance and the mentioned international instruments.

\section{The principles of good governance}

The search for a governance system that works well is as old as the idea of government itself. The concept of good governance was however again brought to the fore in 1989 in a report by the World Bank on the economic and development problems of sub-Saharan Africa. ${ }^{4}$ The report reflected on why structural adjustment programmes had failed to create economic growth.

In the foreword to the report the then president of the World Bank, Barber Conable, stated:

A root cause of weak economic performance in the past has been the failure of public institutions. Private sector initiative and market mechanisms are important, but they must go hand-in-hand with good governance - a public service that is efficient, a judicial system that is reliable, and an administration that is accountable to its public. ${ }^{5}$

It was also stated in the report: ${ }^{6}$

The rule of law needs to be established. In many instances this implies rehabilitation of the judicial system, independence for the judiciary, scrupulous respect for the law and human rights at every level of government, transparent accounting of public monies and independent public auditors responsible to a representative legislature, not to an executive. Independent institutions are necessary to ensure public accountability. The widespread perception in many countries is that the appropriation of the machinery of government by the elite to serve their own interests is at the root of this crisis of governance. The willingness of the donor community to tolerate impropriety - by failing to insist on scrupulous conduct by their own suppliers, by not ensuring that funds are properly used, by overlooking inadequate accounting and auditing, and by tolerating

$4 \quad$ World Bank Report Sub-Saharan Africa.

5 Ibid at xii.

$6 \quad$ Ibid at 192. 
generally lax procurement procedures - aggravates the malaise. Everyone avowedly deplores the situation and wishes it were otherwise. But it will not be so until accountability is instituted.

One of the aspects identified by the World Bank, in the 1989 report, as part of good governance, was the overhaul of the procurement policies of some states. ${ }^{7}$ This was seen as a prerequisite for sustainable growth and the continued provision of aid by many international organisations.

The concept of good governance gained momentum in that many international organisations, in particular those involved in developmental and financial assistance, to ensure that the financial assistance be properly directed, required good governance by a borrowing state. ${ }^{8}$

The debate on good governance was not limited to Africa and in the context of governance in the European Union it led to the White Paper on European Governance being published by the European Commission in July $2001 .{ }^{9}$ Good administration was seen as part of good governance. According to the European Commission White Paper on Administrative Reform, ${ }^{10}$ the key principles thereof are service, independence, responsibility, accountability, efficiency and transparency. The above triggered a wide discussion on the concept of good governance and it has become a popular subject for discussion by many. ${ }^{11}$

It is not intended to give a comprehensive definition of good governance as the content of the concept of good governance largely depends on the aims for which it is used. Financial institutions tend to focus more on economic reforms,

$7 \quad$ World Bank Report supra n 5 at 15.

8 Wouters and Ruyngaert Working Paper 69.

9 Commission of the European Communities White Paper 428.

10 Accepted by the Commission on 1 March 2000. See EC White Paper 200.

11 Curtin and Dekker Good Governance. 
whereas the more political organisations focus more on human rights. ${ }^{12}$ We will confine ourselves to a few definitions.

Governance is defined by the United Nations Commission for Global Governance as follows:

Governance is the sum of the many ways individuals and institutions, public and private, manage their common affairs. It is a continuing process through which conflicting or diverse interests may be accommodated and co-operative action may be taken. It includes formal institutions and regimes empowered to enforce compliance, as well as informal arrangements that people and institutions either have agreed to or perceive to be in their interests. ${ }^{13}$

According to the Secretary General of the UN good governance means:

[C]reating well-functioning and accountable institutions - political, juridical and administrative - that citizens regard as legitimate, through which they participate in decisions that affect their lives, and by which they are empowered. Good governance also entails a respect for human rights and the rule of law generally. ${ }^{14}$

The Organisation for Economic Development (herein later referred to as the OECD) defines good governance as follows:

Good governance is the respect for the rule of law, openness, transparency and accountability to democratic institutions; fairness and equity in dealings with citizens, including mechanisms for consultation and participation; efficient, effective services; clear, transparent and applicable laws and regulations; consistency and coherence in policy formation; and high standards of ethical behaviour. ${ }^{15}$

It is defined by the United Nations Economic and Social Commission for Asia and the Pacific as: 
$[P]$ articipation, the rule of law, transparency, responsiveness, consensus oriented, equity and inclusiveness, effectiveness and efficiency and accountability. ${ }^{16}$

Resolution 2000/64 of the UN Human Rights Committee defines it as:

[T]ransparency, responsibility, accountability, participation and responsiveness to the needs of people. ${ }^{17}$

Within the EU, the commission has identified five principles of good governance namely; openness, participation, accountability, effectiveness and coherence. ${ }^{18}$

It can be safely stated that there is agreement about the following core principles of good governance: transparency, accountability, participation, the rule of law, effectiveness, efficiency, proportionality, consistency and coherence. These principles are, generally speaking, also applicable to public procurement.

Good governance in public procurement was also addressed by the World Bank and international organisations like the OECD and the Asia-Pacific Economic Cooperation (herein later referred to as APEC). For purposes of this discussion it is only necessary to deal with the requirement of accountability in public procurement in any detail. The principle of accountability includes at the least democratic control of the administration (for example, attribute supervisory powers to a minister) and the right to effective legal protection.

The World Bank, through its Economic and Sector Work, developed its Country Procurement Assessment Report (herein after referred to as the CPAR) procedure during July 2000. ${ }^{19}$ The CPAR is intended to be an analytical tool to diagnose the health of the existing public procurement system in a country. The questions posed when evaluating accountability are the following:

16 UNESCAP http://www.unescap.org/ 21 Feb.

17 Commission on Human Rights http://www.unhchr.ch/ 21 Feb.

18 Commission of the European Communities supra $\mathrm{n} 9$ at 10.

19 See World Bank http://web.worldbank.org/ 21 Feb. 
a) Are government employees expected to follow a published code of ethics?

b) Is there an accessible and secure process for bidders to report bribes by others and solicitation/extortion of bribes by government officials?

c) Do bidders have adequate access to administrative or judicial review/appeal?

d) Are there measures/initiatives to curb/control corruption, for example, anti-corruption statutes and/or bodies, whistle-blower statutes, comprehensive reforms of the civil service/judiciary, regional initiatives, provisions in the criminal law, anti-bribery provisions, et cetera?

The Development Assistance Committee (herein later referred to as DAC) of the OECD developed guidelines for what they consider to be a well-functioning public procurement system. ${ }^{20}$ Some of the cornerstones identified are integrity and transparency. It includes the availability of mechanisms and capacity for independent control and audit of procurement operations to provide for accountability and compliance. This implies that there must be a system for participants in the public procurement process to lodge complaints and challenge decisions. Administrative and judicial review bodies must have both appropriate levels of independence and the legal power to impose corrective measures and remedies against entities in breach of the legal and regulatory framework. $^{21}$

In the document it is emphasised that such a complaint review and remedy system, provides an important contribution to the compliance environment and integrity of the public procurement system. Such a system must be seen to operate efficiently and fairly and to provide balanced unbiased decisions.

20 DAC http://www.oecd.org/dataoecd/12/14/34336126.pdf 17 Jul. This document was published as part of the Joint OECD/DAC-World Bank Procurement Round Table Initiative after the Third Round Table in Johannesburg in 2004. It's aim is to find reliable and sustainable ways to enhance the functioning of public procurement systems. Available at http://www.oecd.org/dataoecd/12/14/34336126.pdf 21 Feb. Ibid. 
APEC established a Government Procurement Experts Group (herein later referred to as the GPEG) during 1995 to consider ways to achieve increased transparency and liberalisation of government procurement markets. ${ }^{22}$ The GPEG developed a set of APEC Non-Binding Principles on Government Procurement (herein later referred to as NBPs), which were endorsed by APEC leaders at their meeting in 1999 in Auckland, New Zealand. The principles are value for money, open and effective competition, fair dealing, accountability and due process, and non-discrimination. Under accountability and due process is included that mechanisms should be put in place for handling complaints about procurement processes or alleged breaches of procurement laws/regulations/ policies/procedures which cannot be resolved through direct consultation with the procuring agency in the first instance. Such mechanisms should provide for independent, impartial, transparent, timely and effective procedures for the review of such complaints or alleged breaches. In practice, this can include providing for correction of the breaches or compensation for the loss or damages caused, which may be limited to the costs of tender preparation or protest. $^{23}$

The South African Constitution requires public procurement to be done in accordance with a system that is fair, equitable, transparent, competitive and cost effective. ${ }^{24}$ The Constitution also provides that the public administration must be governed by the principles enshrined in the Constitution including, amongst others, the principle of accountability. ${ }^{25}$ The above relates to requirements that can also be classified as prerequisites for good governance in public procurement.

22 APEC http://www.apecsec.org.sg/ 21 Feb.

23 Review of the APEC Non-Binding Principles (NBPS) on Government Procurement, document 2006/SOM3/GPEG/005.

24 Constitution of the Republic of South Africa 1996, s 217 (hereafter the Constitution).

25 S 195. 
From the above it can be concluded that the principle of accountability in good governance in public procurement entails that there must be a system which provides adequate access for the lodging of complaints and challenges by means also of judicial review or appeal. These review and appeal bodies must have the appropriate level of independence and the legal power to impose corrective measures and remedies against entities in breach of the legal and regulatory framework. These mechanisms must be independent, impartial, transparent, timely and effective. The remedies can include the correction of breaches, compensation for loss or damages and may be limited to the costs of tender preparation or protest.

\section{Effective remedies in public procurement as provided for in the Model Law and the GPA}

\subsection{Model Law}

The Model Law makes provision for both administrative and judicial review. ${ }^{26}$ It provides for recourse if any tenderer claims to have suffered, or to in future suffer, loss or injury due to a breach of a duty imposed on a procuring entity.

Provision is firstly made for internal review by the procuring entity itself, or if its decisions have to be approved by an authority, by that authority, ${ }^{27}$ secondly for administrative review, ${ }^{28}$ and lastly for judicial review. ${ }^{29}$ Certain decisions in the procurement process are however not subject to such review by the administrative review bodies. ${ }^{30}$

26 Art 52-57.

27 Art 53.

28 Art 54. The review bodies are provided for in art 52(1).

29 Art 57.

30 Art 52(2). These are: the selection of a method of procurement pursuant to art 18-22; the choice of a selection procedure pursuant to art 41(1); the limitation of procurement proceedings in accordance with art 8 on the basis of nationality; a decision by the procuring entity under art 12 to reject all tenders, proposals, offers or quotations; a refusal by the procuring entity to respond to an expression of interest in participating in requestfor-proposals proceedings pursuant to art 48 (2); and an omission referred to in art 27 (t) 
With regard to internal review, save where the procurement contract has already entered into force, ${ }^{31}$ the complaint must, within 20 days of the date when the tenderer became aware, or should have become aware, of the circumstances giving raise to the claim, ${ }^{32}$ be submitted in writing to the head of the procuring entity, or the approving authority should the decision by the procuring entity be subject to a decision by an approving authority. ${ }^{33}$

If the complaint is not resolved by mutual agreement, a written decision must be issued within 30 days after the submission of the complaint. ${ }^{34}$ Such decision must state the reasons for the decision and if the complaint is upheld, in whole or in part, indicate the corrective measures to be taken. ${ }^{35}$ Such a decision is final unless administrative or judicial review proceedings are instituted. ${ }^{36}$ If a decision is not issued within the specified time the tenderer is entitled to immediately institute administrative or judicial review proceedings. ${ }^{37}$ As soon as such proceedings are instituted the competence of the procuring entity, or approving authority, to entertain the complaint, falls away. ${ }^{38}$

The possibility of administrative review, provided for in the Model Law, is optional as some legal systems do not provide for a hierarchical administrative review procedure. ${ }^{39}$ If administrative review is provided for, the option exists for the administrative review body, either to only make recommendations, or to

(the omission to include certain information in the solicitation documents) or art 38 (s) (the omission to include certain information in the request for proposals).

31 Art 53(1) and (3). Art 53(3) states that a complaint need not be entertained, or continue to be entertained, after the procurement contract entered into force, which creates the impression of it being discretionary. Subs (1) states that unless the procurement contract has been entered into, the complaint shall be lodged with the procuring entity, or approving authority. It seems prudent that once the contract has been entered into the procuring entity or approving authority should be functus officio and any dispute be resolved by another body.

Art 53(2).

Art 53(1).

Art 53(4).

Art 53(4)(a) and (b).

36 Art 53(6).

37 Art 53(5).

38 Art 53(5).

$39 \quad \mathrm{~N}$ to art 54. 
grant one or more of the remedies provided for in the Model Law. ${ }^{40}$ Save for dismissing the complaint the remedies that may be granted by the administrative reviewing body are: ${ }^{41}$

a) to issue a declaration of the legal rules or principles that govern the subject-matter of the complaint; ${ }^{42}$

b) to prohibit the procuring entity from acting unlawfully, or to make an unlawful decision, or to follow an unlawful procedure ${ }^{43}$

c) to require the procuring entity that has acted or proceeded unlawfully, or reached an unlawful decision, to act or to proceed lawfully or to reach a lawful decision; ${ }^{44}$

d) to annul, in whole or in part, an unlawful act or decision of the procuring entity, other than any act or decision bringing the procurement contract into force; ${ }^{45}$

e) to revise an unlawful decision by the procuring entity or substitute its own decision for such a decision, other than any decision bringing the procurement contract into force; ${ }^{46}$

f) to require the payment of compensation, as a first option either for any reasonable costs incurred by the tenderer submitting the complaint in connection with the procurement proceedings as a result of an unlawful act or decision of, or procedure followed by, the procuring entity, or as a second option for loss or injury suffered by the tenderer submitting the complaint in connection with the procurement proceedings; ${ }^{47}$ and

g) to order that the procurement proceedings be terminated. ${ }^{48}$

$40 \mathrm{~N}$ to art 54(3).

41 Art 54(3).

42 Art 54(3)(a).

43 Art 54(3)(b).

44 Art 54(3)(c).

45 Art 54(3)(d).

46 Art 54(3)(e).

47 Art 54(3)(f). The Model Law gives two options in this instance, either of which can be adopted by the state enacting the Model Law. Art 54(3)(g). 
Such decision by the administrative review body shall be issued, in writing, within 30 days stating the remedies granted and the reasons for the decision. ${ }^{49}$ Such a decision will be final save if judicial review proceedings ${ }^{50}$ are instituted. $^{51}$

Provision is made for judicial review by a court with jurisdiction, with regard to actions where a tenderer claims to have suffered, or may in future, suffer loss or injury because of the breach of a duty imposed by the law, and petitions for judicial review of decisions made by review bodies, or of the failure of those bodies to make a decision within the time limits prescribed. ${ }^{52}$ The Model Law, as can be expected does not regulate this in any detail as it will depend on the legal system of the country, which adopts the Model Law, what such judicial review will entail. No provision is made as to what remedies should be available in the case of judicial review.

\subsection{General Procurement Agreement}

The GPA promotes an initial consultation process between a supplier and a procuring entity in the event of a complaint by a supplier that there has been a breach of the GPA. ${ }^{53}$ In such an event the procuring entity must timeously and impartially consider such a complaint. This must be done in a manner that is not prejudicial to obtaining corrective measures under the challenge system. ${ }^{54}$

With regard to challenge procedures it is provided that each state party to the GPA shall provide procedures to challenge alleged breaches of the GPA in the context of procurement in which they have or had an interest. These procedures must be non-discriminatory, timely, transparent and effective. ${ }^{55}$ It

49 Art 54(4).

50 Under art 57.

51 Art 54(5).

52 Art 56(6).

53 Art XX:1.

54 Art XX:1.

55 Art XX:2. 
must also be made generally available in writing. ${ }^{56}$ Documentation relating to all aspects of the process concerning procurements must be retained for three years. ${ }^{57}$ Specified time limits may be set for the notification and initiation of the challenge procedures from the time when the basis of the complaint is known or should reasonably have been known. The period may not be less than 10 days. $^{58}$

Challenges must be heard by a court or by an impartial and independent review body. Such body may have no interest in the outcome of the procurement. The members thereof must be secure from external influence during their term of appointment. $^{59}$

The challenge procedures must provide for:

- rapid interim measures to correct breaches of the GPA and preserve commercial opportunities; ${ }^{60}$

- an assessment and a possibility for a decision on the merits of the challenge; ${ }^{61}$ and

- the correction of the breach or compensation for the loss or damages suffered. This may be limited to the cost for preparing the tender or the protest. $^{62}$

56 Art XX:3.

57 Art $X X: 4$.

58 Art $X X: 5$.

59 Art XX:6. A review body which is not a court shall either be subject to judicial review or shall have procedures which provide that: (a) participants can be heard before an opinion is given or a decision is reached; (b) participants can be represented and accompanied; (c) participants shall have access to all proceedings; (d) proceedings can take place in public; (e) opinions or decisions are given in writing with a statement describing the basis for the opinions or decisions; ( $f$ ) witnesses can be presented; $(g)$ documents are disclosed to the review body.

60 Art XX s 7(a). Such action may result in the suspension of the procurement process. The procedures may provide that overriding adverse consequences for the interests concerned may be taken into account when deciding whether such measures should be applied. These interests include the public interest. In such instances just cause for not providing interim measures must be provided in writing.

61 Art XX:7(b).

62 Art XX:7(c). 
The challenge procedures must be completed timeously. ${ }^{63}$

It can be concluded from the above that both the Model Law and the GPA provide for detailed challenge procedures in public procurement. Such challenges must be heard by an impartial and independent body, which may be an administrative or judicial body. Provision can be made for both administrative and judicial recourse. The procedures must be timely, transparent and effective. In the case of damages suffered by the complainant such damages may be limited to the reasonable costs incurred. ${ }^{64}$

As can be expected, as both the Model Law and the GPA are meant to constitute a framework for public procurement, they do not regulate every aspect of public procurement in detail. They do however set forth applicable principles which will ensure good governance in public procurement. In the discussion of the Steenkamp-decision hereunder, the detail will be dealt with to ascertain whether the application of the South African law, in this case, complies with the principles discussed above.

\section{The Steenkamp-case}

\subsection{Facts}

In Steenkamp v Provincial Tender Board, Eastern Cape ${ }^{65}$ the plaintiff was the liquidator of a company by the name of Balraz (Pty) Ltd. The company was, prior to its liquidation, awarded a tender and entered into a contract with the provincial government for the delivery of services related to an automated cash payment system for social and other grants in the Eastern Cape. The award of

63 Art XX:8.

64 It is interesting to note that in the EEC no reference is made that damages can be limited to costs incurred in the case of an infringement of the directives on public procurement. Directive 89/665/EEC art 2 states with regard to public procurement that Member States shall ensure that the measures taken concerning the review procedures include provisions for the power to award damages to persons harmed by an infringement. 
the tender and contract with Balraz was later set aside upon application for review by one of the unsuccessful tenderers. ${ }^{66}$ Balraz's liquidator claimed outof-pocket expenses, consisting mainly of director's and consultants' remuneration, the company incurred after being awarded the tender. ${ }^{67}$ The Interim Constitution ${ }^{68}$ and the Provincial Tender Board Act (Eastern Cape) ${ }^{69}$ were applicable to the tender proceedings. The claims instituted by the liquidator were based on delict and contract.

Exceptions were taken against both claims in that it was alleged that the particulars of claims did not constitute causes of action. The exception against the claim based on contract was upheld and the matter was referred to trial on the claim based on delict. With regard to the alleged delict, the plaintiff had to prove, amongst others, unlawfulness and negligence. The averments by the plaintiff were that the tender board owed Balraz a legal duty and that it negligently failed to discharge that duty. The legal duty was averred to be as follows:

[T]he Board owed Balraz a duty in law to (i) exercise its powers and perform its functions fairly, impartially and independently; (ii) take reasonable care in the evaluation and investigation of tenders; (iii) properly evaluate the tenders within the parameters imposed by tender requirements; and (iv) ensure that the award of the tender was reasonable in the circumstances. ${ }^{70}$

It was common cause that Balraz was not incorporated as a company when the tender was submitted. For this reason, the court a quo held that the tender submission by Balraz was invalid and that the tender board did not owe it any legal duty. The claim was dismissed as unlawfulness was not proved. ${ }^{71}$ The matter went on appeal to the Supreme Court of Appeal where the decision by

66 See the decision in Cash Paymaster Services (Pty) Ltd v Eastern Cape Province ao 1999 (1) SA 324 Ck.

67 At 155-156.

68 Constitution of the Republic of South Africa 200 of 1993.

69 Provincial Tender Board Act 2 of 1994 (EC).

70 At 156.

71 At 157. 
the court a quo was upheld. A further appeal was thereafter heard by the Constitutional Court.

\subsection{The courts a quo on unlawfulness}

The court a quo, which dealt with the exceptions against the claims, held, with regard to the claim based on delict, that any act or omission by the tender board that would result in a person suffering damages, would be unlawful as the board cannot act as it pleases and cause loss to others. It therefore dismissed the exception against the particulars of claim based on delict and referred the matter to trial on the delictual claim. ${ }^{72}$

The trial court approached the matter more guardedly. It held that all tenderers are entitled to a lawful and fair process, according to the legislation governing procurement, which was enacted in the interest of the tenderers and the state. Should the process be flawed, an unsuccessful tenderer may apply for review. An initially successful tenderer, whose contract is declared void by the review court, however has no remedy except possibly a claim for damages. The trial judge was not of the opinion that to award damages to parties such as Balraz would unduly hamper the board in performing its functions, but that it would rather encourage a higher standard of care and conformity with the principle of accountability. It was of the opinion that potential plaintiffs constituted a small number and the argument that to allow such claims would open the floodgates for similar claims was for this reason irrelevant. The judge referred to a duty of care that could arise, depending on the circumstances, if it is foreseeable that a bona fide successful tenderer could incur expenses to perform in accordance with the contract, if, unbeknown to him, the awarding of the contract was defective. Should the tender award and contract subsequently be set aside, such a successful tenderer would suffer loss. However, due to the fact that Balraz never submitted a valid tender, no administrative relationship existed; 
there was no foreseeability of harm and consequently no unlawfulness. ${ }^{73}$ The claim for damages was therefore dismissed.

\subsection{The Supreme Court of Appeal on unlawfulness}

The Supreme Court of Appeal criticised the trail court's use of the term 'duty of care' and held that foreseeability is not always a requirement for unlawfulness. The term 'legal duty', although ambiguous, should rather be used. A legal duty may stem from a statute ${ }^{74}$ or the common law. However, all administrative law duties do not amount to legal duties in the delictual sense. ${ }^{75}$ The first step in the process to determine whether damages are due would be to ascertain whether a statutory or common law duty exists. Although these may overlap, statutory interpretation will determine whether a right of action is conferred following non-conformance with a statutory duty, while policy considerations will be decisive if a common law duty is under consideration. ${ }^{76}$

If a statutory duty was created, the question should be whether the legislature intended to provide for claims for damages. The court therefore applied the 'intention of the legislature' approach to the interpretation of the applicable statute. To determine the intention, the purpose and object of the legislation must be ascertained. The same policy factors that would be relevant in an enquiry whether a common law duty existed will normally be applied. Relying on an English dictum ${ }^{77}$ the court held that no common law duty of care will exist if it is not the policy of the statute to create liability to pay compensation. ${ }^{78}$ If a statutory duty exists and non-compliance thereof gives rise to delictual damages, a common-law legal duty does not exist. If non-compliance of the statutory duty does not give rise to delictual damages, a common-law duty cannot exist either, as this would be in conflict with the statutory scheme. It

73 At 159.

74 The applicable statute being the Provincial Tender Board Act (EC) supra n 69.

75 At 159-160.

76 At 160.

77 Stovin v Wise (Norfolk County Council, Third Party) [1996] AC 923 (HL) 19963 All ER 801 (AC).

78 At $160-161$. 
would be unlikely that a common-law duty would exist if the statute is ambiguous regarding damages. ${ }^{79}$ This construction led to the conclusion that administrative decisions that are authorised by statute, can only give rise to claims for damages if the statute provides as such - reliance cannot be placed on any common-law duty but only on the existence of a statutory duty coupled with a statutory 'policy' or purpose to create delictual liability in cases of noncompliance.

The appellant did not rely on any statutory or constitutional duty for its claim but argued that the duties, mentioned above, were common-law duties that have their origin in the basic principles of administrative law, and that it was merely by chance that the common-law duties overlapped with the duties imposed in terms of the relevant act. The court found this argument problematic as administrative law has now "been subsumed by the constitutional dispensation and every failure of administrative justice amounts to a breach of a constitutional duty". The question is therefore whether the Constitution provides for damages as an appropriate remedy. ${ }^{80}$ The court stated that the "problem becomes more complex" due to the subsequent promulgation of Promotion of Administrative Justice Act 3 of 2000 (PAJA, which does not govern the present case) - and that, referring to the remedies provided for in PAJA,

It may not be without significance that an award for damages is not one of them, although an award of 'compensation' in exceptional circumstances is possible. This could imply that remedies for administrative justice now have to be found within the four corners of its provisions and that a reliance on common-law principles might be out of place. ${ }^{81}$

It is unclear what the 'four corners' of remedies in terms of PAJA would be, as section 8 contains the broad opening phrase allowing a court to grant any order it deems just and equitable including, but not limited to, the orders listed. If the

79 At 161. The court did preface this section with: "One has to concede that our case law is not clear when it comes to drawing the boundary between liability due to the breach of a statutory duty and that of a common-law one. It appears to me that..."

80 At 161.

81 At 161. 
enquiry had been whether the Constitution allows for damages as an appropriate remedy, sections 38 and 172(1)(b) of the Constitution need to have been considered. Section 38 provides that a court may grant any appropriate relief when a right in the Bill has been infringed. Section 172(1)(b) provides that, in addition to the obliged declaration of invalidity of a law or conduct inconsistent with the Constitution, a court may also make any order that is just and equitable, including those listed. The remedies created by the Constitution and PAJA are thus not limited but rather emphasise fairness and equitability. In the present instance there was no need for the court to decide on the above as the claim was not based on a constitutional remedy or PAJA.

The court reiterated that all failures of administrative justice would not be

... per se unlawful (in the sense of contra legem): it simply makes the decision or non-decision vulnerable to legal challenge and, until set aside, it is valid. The award of the tender in this case was not unlawful, it was merely vulnerable. I raise this to indicate that an act by an administrator, which is clearly unauthorised (whether expressly or impliedly) or which violates some or other legal prohibition will probably not be subject to the constraints as to remedy that I have mentioned. For instance, in Cameu the relevant minister was held liable in damages for a purported administrative decision which he was not authorised to make at all. His decision was not only wrong, it was impermissible. Proper categorisation of the administrative error is therefore also important because it is unhelpful to call every administrative error 'unlawful', thereby implying that it is wrongful in the delictual sense, unless one is clear about its nature and the motive behind it. ${ }^{82}$

The court stated that "questions of public policy and the question whether it is fair and reasonable to impose delictual liability are decided as questions of law" - the policy factors relevant in the particular circumstances should therefore be identified and considered, intuitive reaction is unacceptable. ${ }^{83}$ The court then The Cameu-case referred to is a Canadian decision. 
discussed the following issues, before concluding that an action for delictual damages cannot be inferred from the "statute in question": 84

(a) The general approach to delictual liability for pure economic loss caused by administrative breaches; ${ }^{85}$

(b) The duties of the tender board; ${ }^{86}$

(c) Composition and nature of functions of the board; ${ }^{87}$

(d) The disappointed tenderer: Loss of profits; ${ }^{88}$

(e) The disappointed tenderer: Out-of-pocket expenses; ${ }^{89}$

(f) Overkill and accountability; ${ }^{90}$

(g) Availability of other remedies; and ${ }^{91}$

(h) Public versus private tenders. ${ }^{92}$

It can be inferred that the court deemed these issues as relevant policy factors.

The conclusions of the Supreme Court of Appeal on each of the aspects listed, were:

a) South African law follows a conservative approach to the extension of delictual liability and
... although organs of state and administrators have no delictual immunity, 'something more' than a mere negligent statutory breach and consequent economic loss is required to hold them delictually liable for the improper performance of an administrative function. Administrative law is a system that over centuries has developed its own remedies and, in general, delictual liability will not be imposed for a breach of 
its rules unless convincing policy considerations point in another direction. ${ }^{93}$

The law is also not a seamless web and in administrative decisions the courts are concerned with upholding the rule of law and effective decision - making processes, not compensation.

b) The injunctions in the Constitution on procurement and the provincial legislation governing the establishment of the tender board and the procurement process are primarily directed at the tender board, not tenderers. The administrative law duties that follow are not necessarily private law duties that may lead to claims for damages. ${ }^{94}$

c) Most of the members of the tender board were lay persons who, in the view of the court, lacked the requisite knowledge and skill to assess the tenders properly. They were led by advice and submissions. The board was not obliged to accept any or the lowest tender and had to exercise a discretion regarding the weight accorded to several factors in the adjudication of the tenders.

The court then stated, with reference to the decision in Knop, ${ }^{95}$ that:

In general, public policy considerations do not favour the recognition of damages claims for the wrong exercise of a discretion negligently made. ${ }^{96}$

93 At 162-163.

94 At 163-164. The court referred to the judgment in Olitzki, as well as an American judgment where it was held that similar legislation were promulgated with the intention to protect taxpayers and the public, not "material-men and labourers".

95 Knop v Johannesburg City Council 1995 (2) SA 1 (A).

96 At 164-165. The court also referred to a comment by Lord Slynn in an English case, to the effect that authorities who act within their powers are not negligent, but that action beyond the authorisation may be negligent. In such cases "the authority is not exercising a statutory power, but purporting to do so and the statute is no defence." The reference to what can also be termed the board members' incompetence raises the question whether incompetence of a public authority should be accepted as a defence or rather a factor establishing negligence. Even in a country like South Africa where capacity is problematic, the fact that the Constitution requires an effective, efficient and accountable administration should rather lead to acceptance of incompetence as a factor establishing negligence. 
d) A disappointed tenderer is not entitled to claim its loss of profits, resulting from a tender allocation that is merely invalid. A tenderer's 'status' to insist on a proper process is not founded on its rights, but is founded in "the public's interest in the integrity of the bidding process". The public may have to pay for the same public works twice, should claims like these be allowed and such tenderers would be placed in a better position than those tendering in the private sector. ${ }^{97}$

e) A disappointed tenderer will probably be unable to prove that a loss in the form of out-of-pocket expenses is causally connected to an invalid tender allocation, as these expenses "would, in any event, have been incurred and are always irrecoverable irrespective of whether or not the tender was awarded to that party, properly or improperly". The court considered wrongfulness and said:

Unless one is unduly impressed by the floodgate argument, it is difficult to appreciate why the nature of the specific economic loss should make any difference to the scope of the board's legal duty. In other words, there does not appear to me to be a difference in principle between purely economic losses that are out-of-pocket and those of another kind. ${ }^{98}$

f) The court warned against the so called "danger of overkill" and questioned the assumption that the imposition of delictual liability would attain (better) accountability. Instead, it could have a 'chilling effect' on a "young democracy with limited resources," in that tender processes would be considerably slowed down or even grind to a halt. ${ }^{99}$

97 At $165-166$.

98 At 166.

99 At 166-167. The court referred to an argument by an English judge that the imposition of delictual liability on administrative organs might lead to delays in administrative processes due to officials' expected excessive caution, as well as an argument by a Canadian judge that does not share the same apprehension, before apparently opting to follow the first approach. 
g) In Knop ${ }^{100}$ it was stated that the existence of another remedy to rectify an administrative breach, may indicate that claims for damages are excluded. The court supported this statement with a reference to a Canadian case, where it was held that existence of alternative remedies may be indicative of the exclusion of actions for damages, especially where orders on review would adequately rectify matters and the affected person only experienced delay and incurred expenses to invalidate the decision. The court a quo emphasised the fact that Balraz, as successful tenderer, had no alternative remedy, as -

Availability of review to an unsuccessful tenderer can hardly be an argument for conferring a damages claim on the successful tenderer. All that can happen on review is that the tender award may be set aside. The successful litigant does not acquire the benefits (or burdens) of the successful tenderer. Recently a disappointed tenderer, who was able to show that the award was seriously tainted, was vindicated on review, though only by an award of costs since setting aside the award was impractical as the contract work had already been performed. In other words, the suggestion that review is an adequate alternative remedy is a misconception. ${ }^{101}$

Drawing a distinction between the remedies of successful and unsuccessful tenderers is undesirable, as this would indicate that the duties owed to these two groups by a tender board differ. If the successful tenderer cannot claim damages, the unsuccessful tenderer may also not. ${ }^{102}$ The position of a successful tenderer who has entered into a contract and started incurring expenses in order to give effect to the contract, is also clearly different from that of a hopeful tenderer who has incurred expenses in preparation for the tender, or the position of one disappointed tenderer out of a group, who claims a loss of prospective profit.

h) Private contracting parties may not hold each other delictually liable for damages resulting from a void or voidable contract, even if this is the 
result of the fault of one of the parties. The court "can think of no good reason why it should be different where the contract is preceded or affected by an administrative action." ${ }^{103}$

The court in conclusion held that the statute in question did not give rise to a delictual claim for damages that is "purely economic in nature and suffered because of a bona fide and negligent failure to comply with the requirements of administrative justice". 104105

It is important to note that the court did not cite the floodgates argument in support of its decision - it rather emphasised the perceived slowing down of administrative processes that would result from the 'overkill' of imposing delictual liability.

\subsection{The judgements by the Constitutional Court}

Moseneke dcj delivered the judgement on behalf of the majority of seven judges in the Constitutional Court who dismissed the appeal against this decision, while Langa cj and O'Regan j delivered the minority judgement that was also supported by Mokgoro j Sachs j, although concurring with the majority, delivered a separate judgement. ${ }^{106}$ All justices agreed that constitutional issues were raised and that the substantive issue of unlawfulness was under consideration as the Supreme Court of Appeal disposed of the matter on this ground. ${ }^{107}$

103 At 169.

104 At 169

105 Although this finding was adequate for dismissal of the appeal, the court continued to consider the impact of the fact that Balraz was not incorporated at the time it submitted its tender. The court held that it had not existed at the time it tendered and did not have a certificate to commence business - the act of submission of the tender was in fact unlawful and the tender board was not even allowed to consider it. There is no legal duty owed to parties who submit invalid or void tenders. At 69-171.

106 Steenkamp v Provincial Tender Board, Eastern Cape 2007(3) SA 121 (CC).

107 At 130-132. The court stated that procurement is regulated by constitutional provisions and legislation enacted in terms of it, as well as the fact that the exercise and control of public power is always a constitutional matter. S 195 of the Constitution applies. The evaluation and awarding of tenders by tender boards constitute administrative action, in terms of s 38 of the Constitution a court may grant appropriate relief if a fundamental right as been 
The majority judgement commenced with the approval of Steenkamp's now amended contention, as opposed to its arguments in the court a quo and the Supreme Court of Appeal, that although the claim is based on delict, the legal duty relied upon has its origin in the Constitution and controlling legislation. Each "improper performance of an administrative function would implicate the Constitution and entitle the aggrieved party to appropriate relief". Following such a breach the facts, applicable constitutional principles and "the controlling law" should be considered when deciding upon a remedy that should be fair and must vindicate the fundamental right that was violated. The court then distinguished between private and public law remedies:

It is nonetheless appropriate to note that ordinarily a breach of administrative justice attracts public-law remedies and not privatelaw remedies. The purpose of a public law remedy is to pre-empt or correct or reverse an improper administrative function. In some instances the remedy takes the form of an order to make or not make a particular decision or an order declaring rights or an injunction to furnish reasons for an adverse decision. Ultimately the purpose of a public remedy is to afford the prejudiced party administrative justice, to advance efficient and effective public administration compelled by constitutional precepts and at a broader level, to entrench the rule of law.

Examples of public remedies suited to vindicate breaches of administrative justice are to be found in $s 8$ of the PAJA. It is indeed so that $\mathrm{S} 8$ confers on a court in proceedings for judicial review a generous jurisdiction to make orders that are 'just and equitable'. Yet it is clear that the power of a court to order a decision-maker to pay compensation is allowed only in 'exceptional cases'. It is unnecessary to speculate on when cases are exceptional. That question will have to be left to the specific context of each case. Suffice it for this purpose to observe that the remedies envisaged by $s \quad 8$ are in the main of a public law and not private law character. Whether a breach of an administrative duty in the course of an honest exercise of statutory power by an organ of State ought to be visited with a

infringed. They were also in agreement that it would be in the interests of justice to grant leave to appeal as the questions raised were not clear-cut or frivolous. Prospects of success are however not the only factors to be considered - a judgment by the CC would give clarity to tenderers and tender boards regarding their obligations and rights, supra 133. 
private law right of action for damages attracts different considerations to which I now turn. ${ }^{108}$ (Footnotes omitted.)

The majority started their consideration of the private law liability by scrutinising the applicable constitutional provisions, being section 217 (the procurement provision) and section 33. Section 217 requires a public procurement system that is fair, equitable, transparent, competitive and cost effective and must be read with section 33. The provincial tender boards function, and may only act in terms of the applicable provincial legislation. ${ }^{109}$ The discretions conferred upon it must be exercised honestly and it may not negligently or recklessly disregard "the protectable interests of tenderers". It was common cause that the tender board acted in good faith but in conflict with the precepts of administrative law, however, this does not automatically lead to a finding that a legal duty was breached.

In our constitutional dispensation every failure of administrative justice amounts to a breach of a constitutional duty. But the breach is not an equivalent of unlawfulness in a delictual liability sense. ${ }^{110}$

The state is not immune against claims based on invalid administrative action, but the negligent breach of a statutory duty that causes loss is not enough to establish liability

... [p]olicy considerations of fairness and reasonableness have to be taken into account when imposing a duty of care and ultimately liability to make good the harm suffered by a claimant. ${ }^{111}$

Reference was made to the statement in $\mathrm{Knop}^{112}$ that the intention of the legislature regarding creation of a statutory legal duty should be the fundamental factor determining delictual liability. ${ }^{113}$

108 At 134-135.

109 The court concluded that the final Constitution applied, as the proceedings were not pending when it came into operation, Steenkamp v Provincial Tender Board, Eastern Cape 2007(3) SA 121 (CC) 136.

110 At 137.

111 At 137.

112 Knop v Johannesburg City Council 1995 (2) SA 1 (A).

113 At 137-138. 
The common law test for unlawfulness ${ }^{114}$ in case of omissions is that the court has to find that a failure to fulfil a legal duty existed and that such failure caused harm. The existence of a legal duty will be a value judgement on what is reasonable and will also include the court's assessment of the "common convictions of society". ${ }^{115}$ The principle laid down in Olitzki ${ }^{116}$ applies - the empowering constitutional and statutory provisions have to be interpreted, but a common-law duty also requires that the court find it just and equitable to allow a civil claim for damages. The reasonableness of the imposition of liability for damages depends on a court's "appreciation of the sense of justice of the community" and during this enquiry "broad considerations of public policy", with reference to the Constitution, must also be taken into account. ${ }^{117}$ As stated in Knop, the assessment of unlawfulness is an assessment of objective reasonableness and the boni mores, that is the value judgement encompassing "all the relevant facts, the sense of justice in the community and considerations of legal policy" which are all now based on the values of the Constitution. ${ }^{118}$ The relevant facts will include -

... whether the operative statute anticipates, directly by inference, compensation for damages for the aggrieved party; whether there are alternative remedies such as an interdict, review or appeal; whether the object of the statutory scheme is mainly to protect individual or advance public good; whether the statutory power conferred grants the public functionary a discretion in decisionmaking; whether an imposition of liability for damages is likely to have a 'chilling effect' on performance of administrative or statutory function; whether the party bearing the loss is the author of its misfortune; whether the harm that ensued was foreseeable. ${ }^{119}$

The majority then considered two main issues: the availability of remedies and the possible development of the common law.

114 The term 'wrongfulness' was used, but again the submission is that in delictual context the term 'unlawfulness' is more appropriate.

115 At 138.

116 Olitzki Property Holdings v State Tender Board 2001 (3) SA 1247 (SCA)

117 At 138-139.

118 At 139.

119 At 140. 
Appellant contended that the legal convictions of society may demand that successful tenderers in the position of Balraz be afforded a remedy in delict, due to the following factors: In terms of the contract concluded after awarding of a tender, the successful tenderer must perform and has to incur expenses in order to do so. The liability would not be for vast amounts, as it would be limited to expenses actually incurred. Liability would only be established once negligence and causation has also been proved. By imposing delictual liability, tender boards will be careful to act in accordance with the constitutional values of governmental transparency and accountability. ${ }^{120}$

The majority expressly declined to express an opinion on the extension of delictual liability in cases of "pure economic loss". ${ }^{121}$

In their consideration of the submissions by appellant, the majority commenced with the statement that the absence of an express prohibition of an action for damages in the controlling legislation, is not decisive. On the contrary - there is no provision in the legislation that explicitly states or implies that "an improper but honest exercise of the discretion of the tender board must attract a delictual right of action in favour of a disappointed tenderer". ${ }^{122}$

The majority disagreed with the contention that a successful tenderer like Balraz is left without remedy - although it may not apply for review or an interdict, it may tender again when the process is restarted. A prudent tenderer would also negotiate a contractual term allowing restitution of expenses incurred in performance of the contract and should exercise caution in incurring such expenses. In reaching this conclusion, the majority assumed that the tenderer was an equal contracting party when negotiating the terms of the

120 At $140-141$.

121 At 141.

122 At 141-142. Moseneke dcj made use of the term 'disappointed' - it is not clear whether the reference is to unsuccessful tenders or all tenderers who are dissatisfied about something. 
contract after it has been awarded and that a contractual provision regulating such occurrences would be better than allowing

a blunt remedy of recognising a generic duty of care in relation to out-of-pocket expenses incurred on the back of a tender award. ${ }^{123}$

The majority held that the common law need not be developed to allow claims for damages for out-of-pocket expenses incurred by a successful tenderer whose tender is subsequently set aside. Two main reasons were:

- The fact that the losses were 'out-of-pocket' is irrelevant - public policy "is slow to recompense financial loss of disappointed tenderers" and the kind of financial loss does not alter this.

- "[E]ven if there may not be a public law remedy such as an interdict, review or appeal, this is no reason for resorting to damages as a remedy for out-of-pocket loss". The reason for this is that the loss "may be avoided" and because "it is not justified to discriminate between tenderers only on the basis that they are either disappointed tenderers or initially disappointed tenderers". Differentiation of this sort would imply that tenderers are allocated different rights in "the same tender process" and differentiation is not justified as all initial tenderers may take part in the new tender process after setting aside of the first tender. ${ }^{124}$

Although not elaborated upon, the majority stated that it agreed with "several significant findings" of the Supreme Court of Appeal ${ }^{125}$ and then listed three findings it "particularly" agreed with:

a) "Compelling public considerations require that adjudicators of disputes, as of competing tenders, are immune from damages claims in respect of their incorrect or negligent but honest decisions." Policy considerations may 
differ in cases where decisions are made in bad faith, corruptly or "completely outside the legitimate scope of the empowering provision". ${ }^{126}$

b) The primary aim of the controlling legislation is the establishment of "a fair tendering process in the public interest". The factual context and relevant policy considerations may warrant imposition of liability where the controlling legislation has a "manifest purpose to extend protection to individual members of the public or groups". ${ }^{127}$

c) Allowing delictual claims for damages against tender boards, would compromise the "invaluable public role of tender boards". Review applications by unsuccessful tenderers will be followed by delictual claims by initially successful tenderers and this "spiral of litigation is likely to delay, if not weaken the effectiveness of or grind to a stop the tender process". Again the majority equated the position of successful and unsuccessful tenderers by stating that the meagre resources of the treasury would be severely taxed if damages were paid to "disappointed or initially successful tenderers and still remain with the need to procure the same goods or service" - this would be to the detriment of the public at large. ${ }^{128}$

Although the majority raised the question of validity of the tender and approved the finding that Balraz did not exist and did not act in terms of a preincorporation agreement when it submitted the tender, it expressly refrained from deciding upon the validity of the tender. It did not consider negligence. ${ }^{129}$

129 At 144-146. The minority also did not consider the validity of the tender although apparently in support of such a finding (at 157-158). However, they indicated that the parties had agreed that the question of negligence should be referred back to the trial court, should a finding of wrongfulness ensue, at 147. It is important to note that the narrow question was whether the negligent awarding of a tender could be unlawful negligence as factor establishing liability was never considered, only the fact whether assumed negligence could give rise to a breach of a legal duty. 
The minority judgement was delivered by Langa cj and O'Regan j, who only considered the question of unlawfulness, as damages can only be claimed if the conduct causing the damages was unlawful, rephrased, if a legal duty was owed. They decided the question of unlawfulness with full acknowledgement that the damages in question constituted pure economic loss. ${ }^{130}$ Like the majority, they emphasised that the test for unlawfulness is a normative enquiry based on the norms and values of society, also as reflected in the Constitution. In the process, relevant norms have to be identified and analysed. ${ }^{131}$

The empowering statute has to be considered as a starting point. The minority also took into account the principles that the tender board had to operate fairly, impartially and independently and that the tender system they had to devise, had to be fair, public and competitive - principles that were laid down in the Interim Constitution. ${ }^{132}$ In addition, these principles (and other in the empowering statute) have to be read in the light of the constitutional administrative justice clause, as this clause is aimed at protection of the rights of participants in the tender process. ${ }^{133}$ The absence of any provision dealing with appeal or review in the empowering statute is of importance as the ordinary rules of administrative law apply. The existence of an internal remedy has previously been regarded as a factor that may exclude delictual liability. ${ }^{134}$

The empowering statute is silent on claims for damages. Relevant normative principles should therefore be identified and considered in order to establish whether the conduct in question was unlawful, taking into account what is just and reasonable in accordance with the court's appreciation of the community's sense of justice, which includes public policy considerations determined by the Constitution and the impact the decision will have upon the plaintiff. ${ }^{135}$ 
They agreed that an unsuccessful tenderer should not be awarded damages for a loss of profits, ${ }^{136}$ but distinguished the present case from the facts in Olitzki on two grounds: ${ }^{137}$

a) After awarding of a tender the successful tenderer is obliged to perform in terms of the contract and will institute processes to comply with its contractual obligations. The unsuccessful tenderer may apply for review to enforce his rights and resubmit a tender, whereas the successful tenderer is left without a remedy to recover expenses. ${ }^{138}$ It is undesirable that tenderers who are awarded government contracts should hesitate to start fulfilling their contractual obligations. They criticise the majority for implying that tenderers should do this, as this

... would undermine the constitutional commitments to efficiency and the need for delivery which are of immense importance to both government and citizens alike. ${ }^{139}$

b) Claims for out-of-pocket expenses are much smaller than claims for loss of prospective profit. Refusal of claims for out-of pocket expenses by successful tenderers "may well render smaller and less financially viable tenderers at risk of liquidation." Empowerment companies, which are normally new and financially vulnerable, are often awarded tenders in accordance with government's policy of economic empowerment and transformation - if they are expected to incur expenses in order to meet contractual obligations, but are then left without a delictual claim for damages, they will be financially ruined. There is a marked difference between claims for loss of prospective profits and claims to recover "actual money spent in good faith ... in pursuance of contractual obligations..." as

136 At 151-152. Referring to claims by unsuccessful tenderers for loss of prospective profits, the minority said: "Whatever the situation may be in society wealthier than ours, to afford an unsuccessful tenderer such a claim in our society would unduly burden the public purse that is already beset with more legitimate claims than it can possibly meet."

137 At 151-153.

138 At 151.

139 At 152. 
this is a "reimbursement for expenses undertook for the benefit of the government". ${ }^{140}$

Liability will enhance accountability in these particular circumstances, but this is not the "determinative criterion", as accountability need not always translate into delictual liability, as held in Van Duivenboden. ${ }^{141}$ The most important consideration in favour of tenderers like the present plaintiff is

... the need to ensure that it is compensated for its bona fide expenses, and that it would be unwise not tot do so because of the harmful effect that may have on the performance of tender obligations. $^{142}$

The minority did not attach the same weight to the four other considerations put forward by the majority.

They doubted that the successful tenderer would have an alternative effective remedy at its disposal - even if the initially successful tenderer successfully participates in a second process, after the initial contract is set aside, it will not be able to recover expenses incurred after being awarded the first contract. ${ }^{143}$ It is unlikely that tenderers have the negotiating power to insist upon inclusion of compensation clauses in contracts with the state, but even if they did, the legal duty of the tender board not to act negligently outweighs the possibility of such bargaining ability. ${ }^{144}$

The minority agreed that adjudicators should not be held liable for their negligent but bona fide decisions, but the decision of a tender board to award a tender, is administrative action. Classification of administrative action as

140 At 152-153. Allowing claims for loss of prospective profit would be undesirable as it would amount to allowing windfalls and would unduly burden the public pursue that is already strained by demands on it due to constitutional obligations and the need for social and economic reform, as stated in Fose.

141 Minister of Safety and Surity v Van Duivenboden 2002 (6) SA 431 (SCA).

142 At 153.

143 At 154.

144 At 154. 
judicial, quasi-judicial or purely administrative has been held to be untenable and the categorising of awarding of a tender as 'adjudicative', constitutes a return to this flawed approach. The nature of the tender board's functions is such that delictual claims may or may not be allowed, depending on the circumstances. ${ }^{145}$

The purpose of procurement legislation is indeed to ensure fair procurement processes in the public interest, but also to protect the rights of participants in the process. If interpreted as such, delictual liability may ensue. ${ }^{146}$

The 'chilling effect' argument is indeed valid, and should be afforded greater weight than the 'alternative remedy' argument. However, the minority did not foresee the same potential impact as the majority as the losses that could be claimed would only be those expenses incurred as a result of the awarding of the tender, normal running costs would not even have to be allowed. ${ }^{147}$

The minority was of the opinion that the majority attached the greatest weight to their assessment of the nature of the functions of the tender board and the chilling effect delictual liability would have on performance by tender boards and the fiscus. They stated that the following four factors outweighed these two:

a) The nature of the damages under consideration coupled with the "desirability of reimbursing successful tenderers for such expenses". ${ }^{148}$

b) The constitutional administrative justice clause "seek[s] to vindicate the right to administrative justice" of participants in the tender process.

c) Performance of government contracts may be compromised if successful tenderers are left without remedy in respect of expenses incurred to fulfil contractual obligations. 
d) Empowerment companies may be those hardest hit by declining a delictual remedy, while there is a need for such companies to continue to partake in the economy. ${ }^{149}$

The minority recognised the possibility that section 8(1)(c)(ii)(bb) of PAJA may in future be developed to properly vindicate the right to administrative justice, but PAJA did not apply to the case. ${ }^{150}$ The shorter period prescribed by PAJA in which proceedings for review must be instituted, will probably limit wasted expenses by successful tenderers. ${ }^{151}$

Sachs j, in his separate judgement, agreed with the majority that delictual liability is inappropriate, but for a different reason. He regarded it undesirable to "develop private law remedies to fill the gap" in instances where losses caused by invalid administrative action is sought to be recovered. One of the implications of the adoption of administrative justice as a fundamental right, is in his opinion

... that a constitutionalised form of judicial review is intended to cover the field, both in substance and remedial terms. To my mind it would not only be jurisprudentially inelegant and functionally duplicatory to permit remedies under constitutionalised administrative law, and remedies under the common law, to function side by side. It would be constitutionally impermissible. ${ }^{152}$

He acknowledged that PAJA did not apply at the time the events took place, but regarded it as an important expression of public policy at the time. He was also of the opinion that a compensation order was possible before enactment of PAJA, based on the judgement in Fose ${ }^{153}$ that opened the door for the possibility of constitutional damages. Section 8(1)(c)(ii)(bb) of PAJA is merely the articulation of the public law remedy already implicit in the Constitution. Had

149 At 156.

150 At 157. The minority also referred to the fact that two directives in the European Union oblige member states to ensure that adequate remedies exist and "specify the remedies that reviewing bodies should have at their disposal".

151 At 157.

152 At 158-159.

153 Fose $v$ Minister of Safety and Surity 1997 (3) SA 786 (CC). 
such an innovative, constitutionally based remedy been pleaded, the difficulties in both the majority and minority judgements could have been avoided. ${ }^{154}$

\subsection{Remarks}

It is doubtful whether tenderers are really in a position to negotiate the terms of the contract with government, as the minority also states. Tender documents usually contain pro forma contracts or a set of tender conditions, drawn up by the public entity, that have to be accepted by prospective tenderers, failing which the tender is not accepted. In the case of state tenders national treasury, in 2003, issued standard bidding documents and general conditions of contract to which all bids and contracts must be subject and of which the wording may not be amended. ${ }^{155}$ The state can and probably will decline to include terms in the contract that will favour the tenderer, as it is not legally bound to do so. The state is not under these circumstances liable to compensate expenses incurred and will certainly not opt to contract to the contrary.

The majority stated that successful tenderers may not "leap without looking", that "Balraz should have curbed its commercial enthusiasm" and that "Balraz unnecessarily chose the more hazardous course which is to incur mainly salary expenses of its directors without fashioning an appropriate safeguard". ${ }^{156}$ It is submitted that these factors are indeed relevant, but not during the enquiry as to unlawfulness. The amounts spent and the items they were spent on will have to be considered during the causation enquiry. Determination of unlawfulness should take place first, then the consideration of causation. A successful tenderer who had no share in irregularities that lead to the setting aside of a tender award, is indeed required by law to perform in terms of the contract and expenses that are incurred directly as a result of this should be seen in a different light than those that would have been incurred regardless. As the

154 At 158-159.

155 Practice note number SCM1 of 2003, issued by National Treasury as provided for in the Treasury Regulations "Framework for Supply Chain Management" promulgated in GG25767 of 5 Dec 2003 in terms of s 76(4)(c) of the PFMA supra $n 2$.

156 At 143. 
minority stated, running expenses will normally not be causally linked to the awarding of the tender. Indeed Balraz's expenses were mostly directors' salaries that would probably have been incurred in any event, but the basis for dismissing the claim should then have been lack of an adequate causal link, not absence of unlawfulness.

If a successful tenderer was contractually obliged to perform at the time it incurred expenses directly related to the execution of the tender, it indeed placed him in a position quite different to the unsuccessful tenderer who simply did not have such a duty. A valid distinction can therefore be made between a successful and an unsuccessful tenderer - an unsuccessful tenderer never incurs expenses in order to perform in terms of the contract, the successful tenderer must.

The majority concentrated on whether there was an alternative remedy available and declined to allow claims for damages - when asked to consider a development of the common law, in the form of the recognition of a legal duty, neither the constitutional values and norms nor the applicable fundamental rights were considered. Although Moseneke dcj did state that he agreed with "several significant findings" of the Supreme Court of Appeal, one would have expected reference to the applicable constitutional provisions and principles that applied to the case. Instead, the majority focused on the position of disappointed tenderers and the undesirability to differentiate between successful and unsuccessful tenderers.

Comparisons were also made to tenderers who take part in tender processes in the private sector. One of the reasons for denial of a claim for damages was that tenderers in the public sector should not be allowed claims for damages if no such claims are allowed in the private sector. Although this appears to be an attractive argument, there are vast differences in the two processes. Tenders in the private sector are not similarly governed by fundamental rights, constitutional procurement provisions and principles of good governance. Public procurement processes are and because of this, aggrieved parties may 
approach a court to set aside the awarding of a tender on a number of grounds. This is not the case in the private sector where the freedom to award a tender is not regulated to this extent and where successful tenderers are not as vulnerable to potential review applications and subsequent setting aside of contracts.

The majority stated that public policy may well allow claims for damages if, inter alia, decisions were made "completely outside the legitimate scope of the empowering provision". ${ }^{157}$ It is uncertain when a decision will qualify as such will an unreasonable decision by a bona fide administrator qualify? Or a decision by an unauthorised administrator? Will an irrational decision by an incompetent but bona fide administrator qualify? Or a decision based on a manifestly unfair procedure? Must one, two, three or four grounds of review be present? The problem with such an approach is that it attempts to categorise the grounds of review and introduces the idea of grades or levels of "wrongness". The grade or level of negligence or even ignorance will then determine the lawfulness or unlawfulness of an administrative decision. Where will the boundaries be drawn? In the matter of Minister of Finance $v$ Gore ${ }^{158}$ the Supreme Court of Appeal held that a delictual claim for damages does lie against the procuring entity in the case of fraud. The court held that unlike in the Steenkamp matter wrongfulness did exist. It was of the opinion that unlike in the Steenkamp and Olitzki cases, where it was said that the imposition of delictual liability for loss of profit and out of pocket expenses in the case of an innocent wrong awarding of a tender, was too high for the public purse, the cost to the public of exempting fraudulent conduct would be too high. ${ }^{159}$

The majority held that the legislation controlling procurement is mainly aimed at ensuring a fair tender process in the public interest, by implication not to protect individual members of the public. All these individual members of the public still

157 At 144

158 Minister of Finance $v$ Gore 2007 (1) SA 111 (SCA).

159 Par 88. 
have the fundamental right to just administrative action, as stated by the minority. The reasoning of the majority elevates the purpose of legislation to the level where the existence and importance of the fundamental right to administrative justice and other constitutional norms are of secondary importance.

The spiral of litigation foreseen by the majority can be avoided if the administration simply complies with the principles of administrative law. These principles have developed over a long period of time and it is submitted that it cannot be said that it imposes an unreasonable burden on the administration. Courts will not set aside administrative action on any basis - the grounds of review are the requirements for valid administrative action, the fundamental right of every person. Capacity need to be developed by government to ensure that the constitutional requirements of a procurement system which is fair, equitable, transparent and cost effective, are met and that tender boards have a proper understanding of the principles of administrative law.

The argument of the majority that allowing claims for damages would severely deplete the treasury is curious, as the recommendation made earlier in the judgement was that successful tenderers insist upon a clause in their contracts with the state to the effect that all expenses incurred in order to perform in terms of the contract, should be recompensed in case of the setting aside of the awarding of the tender. These amounts would also have to be paid out of the treasury. The dispute before the court was limited to this very narrow category of potential claimants and expenses, not to unsuccessful tenderers or even all expenses incurred by successful tenderers. The nature of a delictual claim is that causation would have to be proved and that all expenses would not necessarily be compensated.

The comments by Sachs $\mathrm{J}$ are obiter as no public law remedy was pleaded. However, it could definitely be heeded by prospective litigants. The judgements by both the Supreme Court of Appeal and nine of the Constitutional justices, were limited to the consideration of delictual liability as pleaded and did not 
exclude the possibility of a public law remedy. A successful tenderer will normally be one of the respondents in an application for review and may request the award of compensation. The unsuccessful tenderer would be the applicant, or one of the applicants. The elements of delictual liability need not be pleaded if section $8(1)(c)(i i)(b b)$ of PAJA is relied upon, as the court is empowered to make any order that is just and equitable. The compensation claimed would have to be substantiated. As unlawfulness and negligence or intent (in the delictual sense) would not be factors under consideration, ${ }^{160}$ the submission is that causation and quantum would have to be proved. The proposed approach will exclude the need for litigants to incur additional litigation costs and will limit delays - all claims could be disposed of in the same procedure.

The clear formulation of the approach to determine unlawfulness in delict by all the justices is welcomed, as the role of constitutional norms is now established in South African law. The existence and breach of a constitutional norm or fundamental right will always be relevant during an enquiry into delictual unlawfulness, but will not per se lead to a finding of unlawfulness, as all circumstances will be considered in the enquiry and normative policy factors will ultimately determine liability.

It is submitted that the composition and functioning of the tender board, in the sense that the board may consist of lay persons who do not understand the intricacies of the tender process or requirements, should not be a decisive factor when the existence of a legal duty is determined. In view of the importance of procurement the state should ensure that properly qualified people serve on tender boards - ignorance or incompetence should not be defences against claims based on infringement of fundamental rights. 


\section{Steenkamp, good governance and the provisions of the Model Law and the GPA}

There can be no doubt that the legal system in South Africa is in accordance with the rule of law and that it ensures accountability in public procurement. Section 217 of the Constitution in effect encompasses the important principles of good governance in public procurement by prescribing a public procurement system that has to be in accordance with a system that is fair, equitable, transparent, competitive and cost effective. The principles of good governance are also reflected in section 195 of the Constitution which provides for the basic values and principles, including those enshrined in the Constitution that should govern public administration. One of these is that public administration should be accountable. ${ }^{161}$ In particular the administrative law of South Africa is well developed and is the right to administrative action that is lawful, reasonable and procedurally fair, provided for in section 33 of the Constitution and does $\mathrm{PAJA}^{162}$ now give effect to these rights.

Both the Model Law and the GPA provides that administrative or judicial review or both should be available in the case of the breach of a legal duty by the procuring entity. As can be expected because of the nature of both the Model Law and the GPA the exact remedies that must be available are not prescribed. It is however of significance that both provide for the possibility of awarding compensation for loss or damages. Such damages may however be limited to the costs of tender preparation or protest.

The fact that the courts decided that no delictual liability was incurred in the Steenkamp-case does not detract in any way from the appropriateness of the South African legal system or the accountability of state organs for their actions in the public procurement process. The possibility exists that damages could have been awarded if had the claim been based on the applicable statutes and

$161 \mathrm{~S}$ 195(1)(f).

162 PAJA was not applicable to the Steenkamp-case as it was only promulgated after the setting aside of the award. 
not on delict. Since the promulgation of PAJA the possibility exists that a court will under similar circumstances allow a claim for damages based on the provisions of PAJA.

No country can ever claim to have a perfect legal system or to have good governance that can not be improved. Different circumstances, priorities, cultures, legal systems and many other differences exist in countries. Due deference must be given thereto when evaluating a procurement system and whether such system complies with the principles of good governance. Whether one is in agreement with the decisions by the different courts that dealt with the Steenkamp-case or not, it can be concluded that the South African public procurement system does in this instance comply with the basic principles of good governance with regard to accountability.

\section{Conclusion}

Although accountability was an important consideration in the Steenkamp-case, it did not lead to a finding of delictual liability, as a number of other measures existed to ensure accountability. The approach by Sachs $j$ is supported for future adjudication of similar cases as PAJA would be applicable. It would save time and costs to dispose of compensation claims at the time of the review application. The submission is that the compensation could be awarded in terms of section $8(1)(\mathrm{c})(\mathrm{ii})(\mathrm{bb})$ of PAJA or in terms of the courts' broadly formulated discretion in the introductory phrase of section 8(1) of PAJA or section 172(1) of the Constitution. 


\section{Bibliography}

Commission of the European Communities White Paper

Commission of the European Communities White Paper on European

Governance 25 July 2001 final 428 (COM Brussels 2001)

Commission on Global Governance Our Global Neighborhood

Commission on Global Governance Our Global Neighborhood (Oxford University Press Oxford1995)

Curtin and Dekker Good Governance

Curtin D and Dekker I "Good Governance: The concept and its application by the European Union" in Curtin D and Wessel R (eds) Good Governance in the European Union (Intersentia Antwerpen 2005)

EC White Paper 200

European Commission White Paper on Administrative Reform, March 2000 volume I and II COM (2000) 200

World Bank Report Sub-Saharan Africa

World Bank Report Sub-Saharan Africa: Crisis to sustainable growth (World Bank Washington DC 1989)

Wouters and Ruyngaert "Good Governance"

Wouters J and Ruyngaert C "Good Governance: Lessons from International Organizations" in Curtin D and Wessel R (eds) Good Governance and the European Union (Intersentia Antwerpen 2004)

Wouters and Ruyngaert Working Paper

Wouters $\mathrm{J}$ and Ruyngaert C Working Paper no 54 Institute for International Law (Katholieke Universiteit Leuven 2004)

\section{Register of legislation}


Constitution of the Republic of South Africa 200 of 1993

Constitution of the Republic of South Africa 1996

Government Gazette 25767 of 5 December 2003

Municipal Finance Management Act 56 of 2003

Promotion of Administrative Justice Act 3 of 2000

Provincial Tender Board Act 2 of 1994 (Eastern Cape)

Public Finance Management Act 1 of 1999

\section{Register of court cases}

Cash Paymaster Services (Pty) Ltd v Eastern Cape Province and Others 1999

1 SA 324 (CC)

Dunn v Minister of Defence and Others 20062 SA 107 (T)

Fose $v$ Minister of Safety and Security 19973 SA 786 (CC)

Knop v Johannesburg City Council 19952 SA 1 (A)

Minister of Finance and Others $v$ Gore NO 20071 SA 111 (SCA)

Minister of Safety and Security $v$ Von Duivenboden 20026 SA 431 (SCA)

Olitzki Property Holdings v State Tender Board and Another 20013 SA 1247

(SCA)

Steenkamp NO v Provincial Tender Board, Eastern Cape 20063 SA 151 (SCA)

Steenkamp NO v Provincial Tender Board, Eastern Cape 20073 SA 121 (CC)

Stovin v Wise (Norfolk County Council, Third Party) 19963 All ER 801 (AC)

Stovin v Wise (Norfolk County Council, Third Party) [l996] AC 923 (HL) 19963

All ER 801 (AC)

\section{Register of Internet resources}

APEC http://www.apecsec.org.sg/ 21 Feb

Asia-Specific Economic Co-operation Government Procurement Experts'

Group [Found on internet]

http://www.apecsec.org.sg/apec/apec groups/committees/committee on $\mathrm{tr}$ ade/government procurement.html [Date of use 21 February 2008]

Commission on Human Rights http://www.unhchr.ch/ $21 \mathrm{Feb}$

Commission on Human Rights The role of good governance in the 
promotion of human rights Resolution 2000/64 [Found on internet]

http://www.unhchr.ch/huridocda/huridoca.nsf/(Symbol)/E.CN.4.RES.2000.6

4.En?Opendocument [Date of use 21 February 2008]

DAC http://www.oecd.org/dataoecd/12/14/34336126.pdf 17 Jul

Development Assistance Committee "Guidelines and Reference Series

Harmonising Donor Practices for Effective Aid Delivery" Volume 3:

Strengthening Procurement Capacities in Developing Countries [Found on internet] http://www.oecd.org/dataoecd/12/14/34336126.pdf [Date of use 17 July 2008]

OECD http://www.oecd.org/ 21 Feb

OECD About Public Governance and Management [Found on internet] http://www.oecd.org/about/0,2337,en 2649374051111 37405,00.ht ml [Date of use 21 February 2008]

UNESCAP http://www.unescap.org/ 21 Feb

United Nations Economic and Social Commission for Asia and the Pacific What is Good Governance? [Found on internet] http://www.unescap.org/pdd/prs/ProjectActivities/Ongoing/gg/governance.a sp [Date of use 21 February 2008]

World Bank http://web.worldbank.org/ $21 \mathrm{Feb}$ World Bank Assessment of Country's Public Procurement System [Found on internet] http://web.worldbank.org/WBSITE/EXTERNAL/PROJECTS/ PROCUREMENT/0, print:Y isCURL:Y contentMDK:20108359 menuPK:8 4285 pagePK:84269 piPK:60001558 theSitePK:84266,00.html [Date of use 21 February 2008]

\section{Register of treaties and international documents}

Non-Binding Principles on Government Procurement 2006/SOM3/GPEG/005 UN Doc A/53/1 


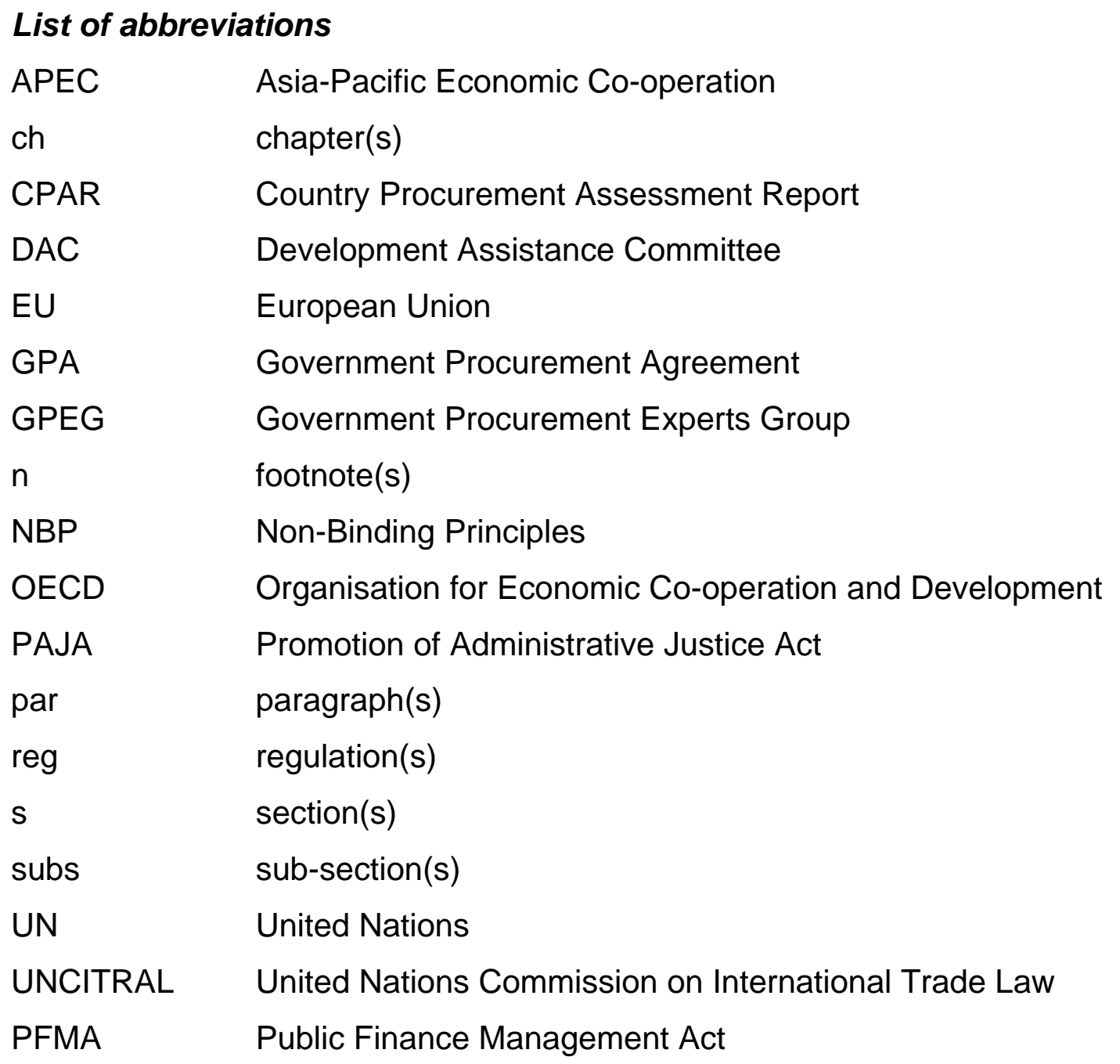

